\title{
TU/e EmonOWEN

\section{A test of lumped-parameter methods for the drying rate in fluidized bed driers for bioproducts}

\section{Citation for published version (APA):}

Kerkhof, P. J. A. M. (1995). A test of lumped-parameter methods for the drying rate in fluidized bed driers for bioproducts. Drying Technology, 13(5-7), 1099-1111. https://doi.org/10.1080/07373939508917011

DOI:

10.1080/07373939508917011

Document status and date:

Published: 01/01/1995

\section{Document Version:}

Publisher's PDF, also known as Version of Record (includes final page, issue and volume numbers)

\section{Please check the document version of this publication:}

- A submitted manuscript is the version of the article upon submission and before peer-review. There can be important differences between the submitted version and the official published version of record. People interested in the research are advised to contact the author for the final version of the publication, or visit the $\mathrm{DOI}$ to the publisher's website.

- The final author version and the galley proof are versions of the publication after peer review.

- The final published version features the final layout of the paper including the volume, issue and page numbers.

Link to publication

\section{General rights}

Copyright and moral rights for the publications made accessible in the public portal are retained by the authors and/or other copyright owners and it is a condition of accessing publications that users recognise and abide by the legal requirements associated with these rights.

- Users may download and print one copy of any publication from the public portal for the purpose of private study or research.

- You may not further distribute the material or use it for any profit-making activity or commercial gain

- You may freely distribute the URL identifying the publication in the public portal.

If the publication is distributed under the terms of Article 25fa of the Dutch Copyright Act, indicated by the "Taverne" license above, please follow below link for the End User Agreement:

www.tue.nl/taverne

Take down policy

If you believe that this document breaches copyright please contact us at:

openaccess@tue.nl

providing details and we will investigate your claim. 
DRYING TECHNOLOGY, 13(5-7), 1099-1111 (1995)

\title{
A TEST OF LUMPED-PARAMETER METHODS FOR THE DRYING RATE IN FLUIDIZED BED DRIERS FOR BIOPRODUCTS
}

\author{
Piet J.A.M. Kerkhof
}

(Laboratory for Separation Technology, Department of Chemical Engineering, P.O. Box 513,5600 MB Eindhoven, the Netherlands, tel : +31-40-472970, fax : +31-40-446104, E-mail : TGTCPK2@CHEM.TUE.NL)

Key-words and phrases : Characteristic Drying Curve, Drying Times, PowerLaw, Prediction, Regular Regime

\section{ABSTRACT}

For batch fluidized bed drying of bioproducts the distributed parameter model is presented, in which the internal diffusion equation is coupled to the air balance equations. In practice a large part of the process takes place at high relative humidity of the drying air, equivalent to low driving forces. The results of a number of lumped-parameter methods for the estimation of drying times are compared with those of the full model for the case of constant external conditions around a particle. For low relative humidity of the drying air predictions of drying times with the Regular Regime Power Law method correspond well with the full solution, for higher ambient RH large deviations occur. The other methods are shown to give large deviations in all cases. 


\section{INTRODUCTION}

Batch fluid bed drying is a process often used for foods and bioproducts. In both types of products the drying rate is influenced by the internal moisture transport inside the particles. In a recent study on the drying of L. Plantarum Lievense et.al. showed that this internal resistance could well be described by an effective diffusion coefficient which is dependent on concentration and temperature (1). In literature several methods of describing and calculating drying curves have been treated, of which most are of a lumped parameter nature : the characteristic drying curve as discussed by Krischer, Keey $(2, \underline{3})$, related methods by Reay \& Allen, McKenzie \& Bahu, Strumillo \& Kudra $(\underline{4}, \underline{5}$, 6), and the Regular Regime approach by Schoeber, Liou, Coumans $(7, \underline{8}, \underline{9}, \underline{10})$. In the present study a comparison is made between the more rigourous diffusion model and the lumped-parameter methods. As an example we have considered the drying of cylindrical particles with the physical properties as determined by Lievense et al (1). A more detailed treatment of the diffusion model is in preparation (11).

\section{MODEL FOR BATCH FLUIDIZED BED OF CYLINDRICAL PARTICLES}

The diffusion equation for non-shrinking particles regarded as infinitely long cylinders reads :

$\frac{\partial \rho_{\mathrm{w}}}{\partial \mathrm{t}}=\frac{1}{\mathrm{r}} \frac{\partial}{\partial \mathrm{r}}\left(\mathrm{rD}_{\mathrm{w}} \frac{\partial \rho_{\mathrm{w}}}{\partial \mathrm{r}}\right)$

The initial and the central boundary condition may be written as :

$\mathfrak{t}=0 \quad 0 \leq \mathrm{r} \leq \mathrm{R} \quad \rho_{\mathrm{W}}=\rho_{\mathrm{W}, 0}$

$t>0 \quad r=0 \quad \frac{\partial \rho_{w}}{\partial r}=0$

For the boundary condition at the interface holds :

$t>0 \quad r=R \quad-D_{w} \frac{\partial \rho_{w}}{\partial r}=j_{w, i}$

in which the interfacial water flux may be written as :

$\left\langle\mathrm{j}_{\mathrm{w}, \mathrm{i}}\right\rangle=\mathrm{k}_{\text {eff }} \rho_{\mathrm{f}}\left(\mathrm{H}_{\mathrm{i}}-\mathrm{H}_{\mathrm{in}}\right)$

in which $\mathrm{H}_{\mathrm{i}}$ and $\mathrm{H}_{\mathrm{in}}$ are the interfacial and bed inlet humidities of the air, $\rho_{\mathrm{f}}$ is the film density, and $k_{\text {eff }}$ is the effective mass transfer coefficient, related to the local mass transfer coefficient by : 
$\mathrm{k}_{\mathrm{eff}}=\mathrm{k}_{\mathrm{loc}} \frac{1}{\mathrm{~N}_{\mathrm{tm}}}\left[1-\exp \left(-\mathrm{N}_{\mathrm{tm}}\right)\right]$

and the number of mass transfer units $\mathrm{N}_{\mathrm{tm}}$ equal to:

$\mathrm{N}_{\mathrm{tm}}=\frac{\mathrm{k}_{\mathrm{loc}} \rho_{\mathrm{f}} \mathrm{A}_{\mathrm{b}} \mathrm{a}_{\mathrm{p}}\left(1-\varepsilon_{\mathrm{b}}\right) \mathrm{L}}{\mathrm{V}}$

with $A_{b}$ the cross-sectional area of the bed, $a_{p}$ the specific area of the particles, $\varepsilon$ $b$ the bed porosity, $L$ the bed height, and $V$ the dry air flow rate through the bed.

Equation (6) follows from integrating the drying air mass balance over the bed, assuming plug flow for the air, and well-mixed solids of which the properties may be regarded constant over the bed height.

The interfacial humidity follows as :

$H_{i}=\frac{A_{w, i} P_{w, s}}{p_{\text {tot }}-A_{w, i} p_{w, s}} \frac{M_{w}}{M_{a}}$

in which $A_{W, i}$ is the water activity related to the interfacial particle-side water concentration $\rho_{W, i}, p_{t o t}$ is the total pressure, $p_{W, s}$ the saturated vapour pressure at the particle temperature, and $\mathrm{M}_{\mathrm{W}}$ and $\mathrm{M}_{\mathrm{a}}$ are the molecular masses of water and air.

Temperature gradients inside the particles are negligable (12), and thus the heat balance may be written as (13) :

$\frac{\pi}{4} \mathrm{~d}_{\mathrm{p}} \rho \mathrm{c}_{\mathrm{p}} \frac{\mathrm{dT}}{\mathrm{dt}}=-\mathrm{j}_{\mathrm{w}, \mathrm{i}}\left(\mathrm{c}_{\mathrm{pv}} \mathrm{T}+\Delta \mathrm{h}_{\mathrm{vo}}\right)+\alpha_{\mathrm{eff}}\left(\mathrm{T}_{\mathrm{in}}-\mathrm{T}\right)$

with $d_{p}$ the particle diameter, $\rho$ and $c_{p}$ the particle density and specific heat, $T$ and $\mathrm{T}_{\mathrm{in}}$ the particle and air inlet temperature respectively, and $\alpha_{\text {eff }}$ the effective heat transfer coefficient, given by :

$\alpha_{\text {eff }} \approx \alpha_{\text {loc }} \frac{1}{N_{\text {th }}}\left[1-\exp \left(-N_{\text {th }}\right)\right]$

and the number of heat transfer units is given by :

$\mathrm{N}_{\text {th }}=\frac{A_{b}\left(1-\varepsilon_{b}\right) a_{p} \alpha_{l o c} L}{V_{c p a}}$

Equation (10) is approximate within a few \%; a detailed account is given elsewhere (13).

The relations used for the local transfer coefficients have been treated elsewhere (12). The set of equations was solved by using a modified Crank-Nicholson scheme similar to that used in spray-drying calculations (14). In Fig.1. the drying curves calculated with the model are compared with the experimental data of Lievense. Good agreement is observed; inspection shows that the 


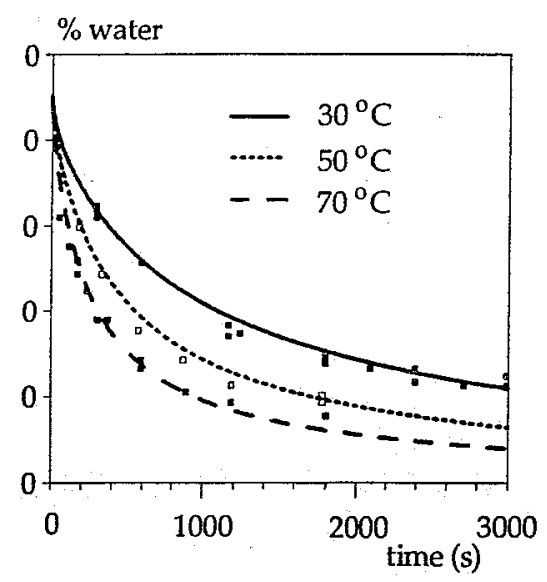

FIGURE 1. Comparison of diffusion model results (drawn line) with experimental data (symbols) of Lievense et al (1) on the drying of L. Plantarum granules. Bed load $50 \mathrm{~g}$, air flow rate $50 \mathrm{~kg} / \mathrm{hr}$, inlet air humidity $0 \mathrm{~kg} / \mathrm{kg}$.

deviations are similar to those in the model fitting performed by Lievense with the power-law regular regime method. In their laboratory experiments they used a small amount of product $(50 \mathrm{~g})$ with a large air flow rate $(50 \mathrm{~kg} / \mathrm{hr})$ in order to ensure a virtually immediate decrease of the surface concentration to the equilibrium value. In Fig. 2 a concentration profiles are shown for a similar laboratory condition at $60^{\circ} \mathrm{C}$ air inlet temperature and $5 \% \mathrm{RH}$, calculated with the above model, showing that indeed the surface concentration decreases very rapidly. To view a typical industrial scale situation a strongly different ratio of bed load $(1000 \mathrm{~kg})$ to air flow rate $(50000 \mathrm{~kg} / \mathrm{hr})$ was used. In Fig. $2 \mathrm{~b}$ the much flatter concentration profiles are shown, which clearly indicate that next to internal diffusion the air uptake capacity has also a considerable influence on the drying rate by decreasing the average driving force.

\section{THE EQUILIBRIUM MODEL}

It is conceivable, as shown in a study by Strumillo et al (15) that the air uptake capacity is the largely dominating factor for the drying rate. In the extreme the 


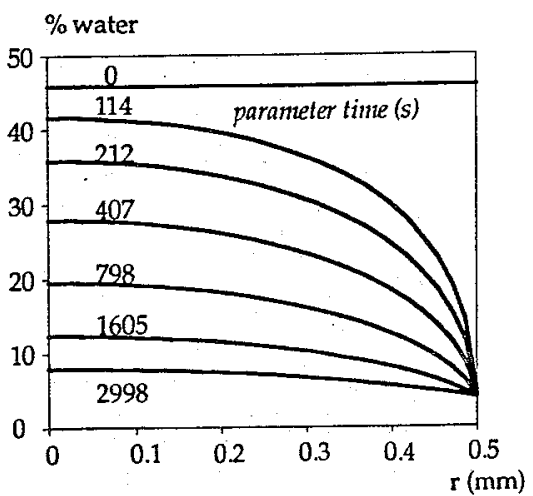

(a)

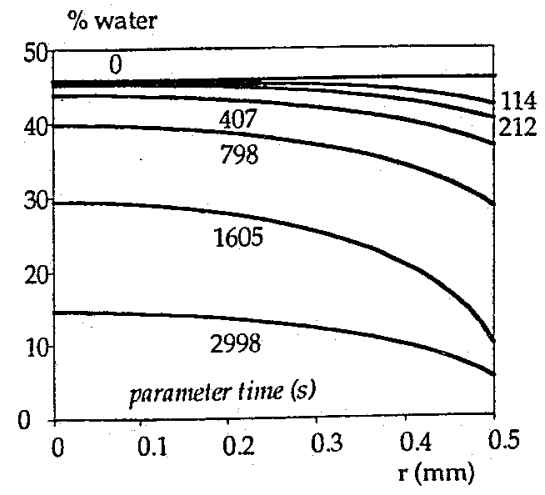

(b)

FIGURE 2. Concentration profiles obtained by simulation for $1 \mathrm{~mm}$ L. Plantarum particles with diffusion model, air inlet temperature $60^{\circ} \mathrm{C}$, air inlet relative humidity $5 \%$. (a) Bed load $50 \mathrm{~g}$, air flow rate $50 \mathrm{~kg} / \mathrm{hr}$. (b) Bed load $1000 \mathrm{~kg}$, air flow rate 50000 $\mathrm{kg} / \mathrm{hr}$.

concentration profiles inside the particles would be flat, and the air would leave the bed at equilibrium with the average moisture content of the particles. In order to estimate the departure from this situation a comparison was made between the drying and temperature history according to the diffusion model for the large bed situation and the situation with infinitely rapid internal diffusion inside the particles, as shown in Fig. 3a. It is clear that the actual drying rate is lower than for the equilibrium model, and the particle heating correspondingly is faster. In Fig.3b the relative humidity of the outlet air is given vs. the water content of the particles, according to both models, for the same conditions as in Fig.2. In view of the high initial solids content the RHG in this case does not have a considerable $100 \%$ region as would be found in other processes, but decreases with decreasing moisture content. The large difference between the diffusion and the equilibrium model is also evident from this picture. Two important conclusions follow from these calculations : internal resistance plays a role in controlling the drying rate, and a large part of the drying process takes place at quite elevated relative humidity levels. 


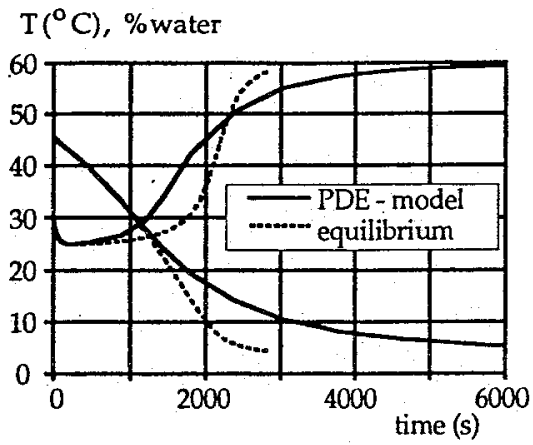

(a)

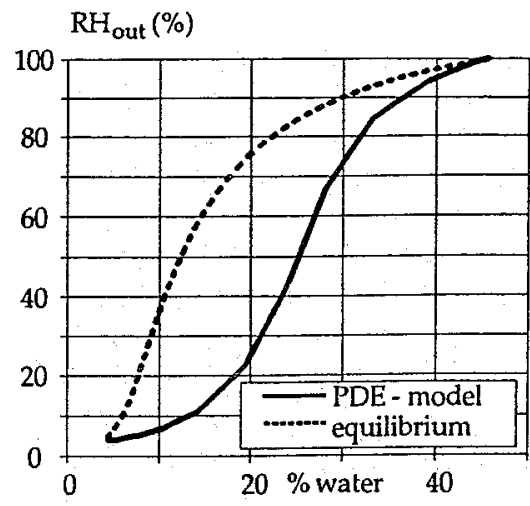

(b)

FIGURE 3. (a) Temperature and moisture content vs. time according to simulation. Conditions equal to those of Fig. 2. (b) Relative humidity of the outlet air vs. average product moisture content in large scale dryer. Comparison between diffusion model (drawn line) and equilibrium model (dotted line).

\section{FURTHER LIMITATION OF SCOPE}

The foregoing shows that in evaluating several lumped parameter methods it is useful to focus also on the influence of the RH. In order to keep complexity to a minimum the dynamic variation of the air conditions during the course of the drying process has been left out in the following, and the considerations are narrowed down to particles with constant external conditions. The basic idea is that these methods have all been based on such situations, which would lead to some kind of standard drying curve depending on external conditions. For variable air conditions it is then assumed that one can make steps between points on the various curves which correspond to the momentary situation. In all further calculations a product amount of $1 \mathrm{~g}$, an air flow rate of $50 \mathrm{~kg} / \mathrm{hr}$, and a bed diameter of $5 \mathrm{~cm}$ was used.

\section{THE CHARACTERISTIC DRYING CURVE}

One of the oldest generalizations is the concept of the characteristic drying curve, as posed by van Meel, and treated in many well-known textbooks e.g. 
Krischer \& Kast (2) and Keey (3), and used in an overwhelming number of papers, reviewing of which is impossible here. The basic assumption is that we can define a dimensionless drying rate :

$$
\begin{aligned}
& -\frac{d X}{d t}=f\left(X^{*}\right)\left(-\frac{d X}{d t}\right)_{c r} \\
& X^{*}=\frac{X-X_{e}}{X_{c r}-X_{e}}
\end{aligned}
$$

in which $X$ is the moisture content on dry basis, and $f\left(X^{*}\right)$ is a function characteristic for the material. The subscript "cr" denotes the reference drying rate in the constant rate period, and for $X$ the critical moisture content. The function $f$ in a general form is often given as :

$$
\begin{array}{cc}
X>X_{c r} & f\left(X^{*}\right)=1 \\
X<X_{c r} & f\left(X^{*}\right)=\left(\frac{X-X_{e}}{X_{c r}-X_{e}}\right)^{a}
\end{array}
$$

For materials in which the constant-rate period is absent as in the present study, $X_{c r}$ is commonly taken equal to the initial moisture content $X_{0}$. In Fig. 4 the value of the relative flux $j^{*}=j_{w, i} / j_{w, c r}$ is plotted logarithmically vs. $X^{*}$, for particles drying at a constant temperature of $30^{\circ} \mathrm{C}$ and different values of the $\mathrm{RH}$ of the surrounding air. It is clear that the relative drying rates show large differences with differing relative humidities, and that " $f$ "-values would differ an order of magnitude. In the middle region of the figure roughly the powerlaw behaviour of Equation (13) would hold, at lower moisture contents however this strongly breaks down. Since a calculated drying time is inversely proportional to the estimation of $f\left(X^{*}\right)$, it is clear that for the present diffusion limited system this method would not work, and any characteristic drying curve from a laboratory experiment at a given $\mathrm{RH}$ would lead to severe errors at other humidities.

\section{METHOD OF STRUMILLO AND KUDRA}

A variant of the characteristic drying curve is the equation given by Strumillo and Kudra (6) :

$$
f=\frac{\left(X-X_{e}\right)^{m}}{A+B\left(X-X_{e}\right)^{m}}
$$

again for the falling-rate period. This would imply that the relative drying rate $f$ 


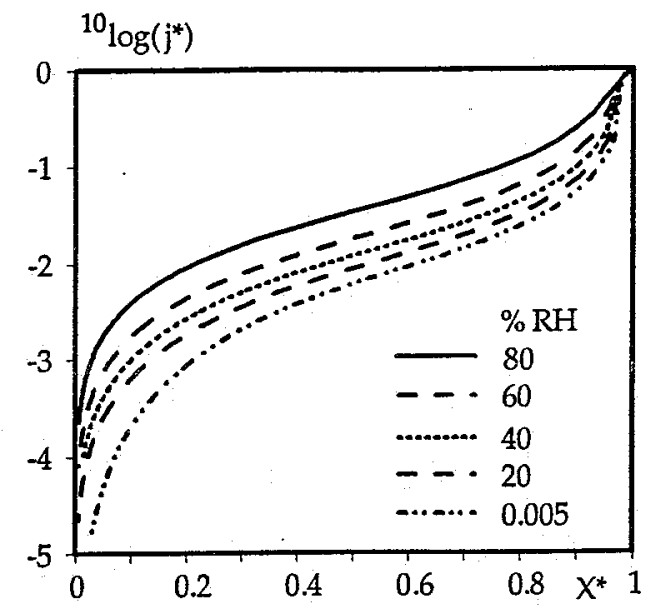

FIGURE 4. Relative flux $j^{*}$ vs. reduced moisture content $X^{*}$ for isothermal drying of particles at $30^{\circ} \mathrm{C}$, for different ambient relative humidities, in order to check Characteristic Drying Curve hypothesis.

would be a unique function of the difference $\left(X-X_{e}\right)$. In Fig. 5 again the relative drying rate is plotted logarithmically, this time vs $\left(X-X_{e}\right)$. It is clear that $f$ is again strongly different at different relative humidities, $1-2$ orders of magnitude. Thus also this method cannot be applied for this type of materials.

\section{METHOD OF REAY, ALLEN, McKENZIE and BAHU}

In a series of papers concerned with the prediction of fluid-bed drying times the mentioned authors next to the effect of relative humidity also included estimates for the effect of temperature $(\underline{4}, \underline{5})$. Analysis of their translation equations for the drying time shows that basically the approach is again Equation (12), but this time with:

$f \sim\left(p_{w, s}-p_{w, i n}\right) X^{*}$

in which $p_{W, \text { in }}$ stands for the water vapour pressure at the inlet of the bed. In Fig. 6a this is tested for this system by plotting the ratio of the water flux and the vapour pressure difference at constant conditions, vs the reduced moisture 


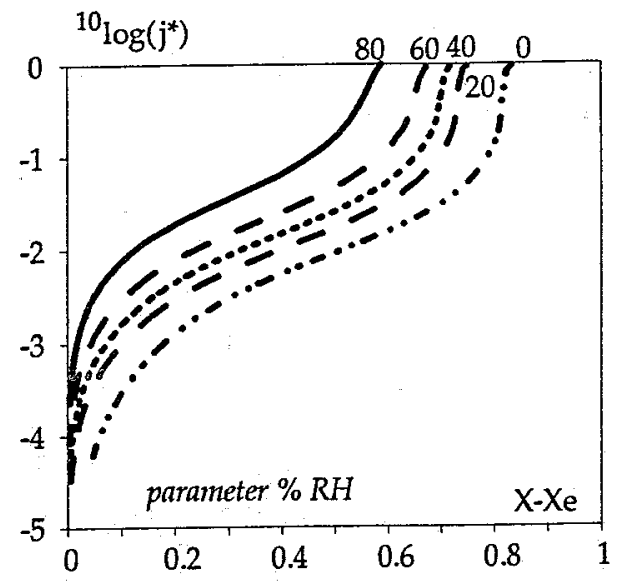

FIGURE 5. Relative water flux is. driving force based on average and equilibrium. product moisture content, for isothermal drying at particle temperature of $30^{\circ} \mathrm{C}$, at different ambient relative humidities, in order to check hypothesis of Strumillo and Kudra

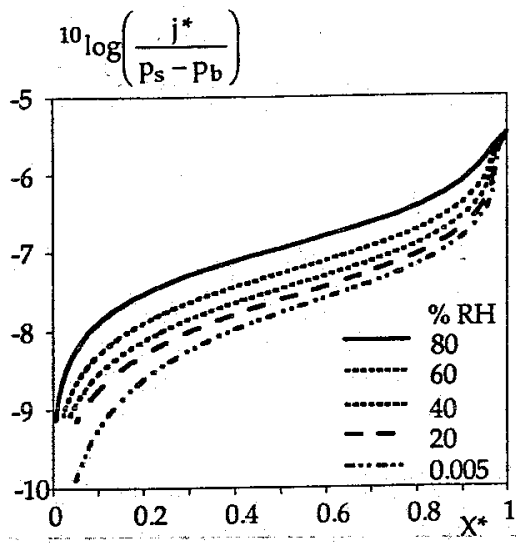

(a)

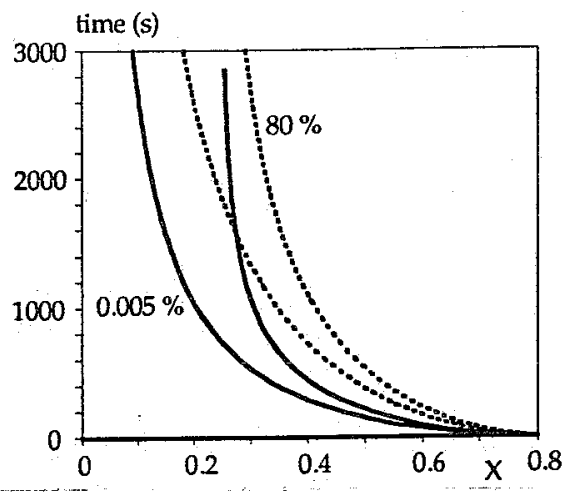

(b)

FIGURE 6.(a) Water flux normalized on gas phase driving force as defined by vapour pressure difference, os. reduced product moisture content, for isothermal drying at particle temperature $30^{\circ} \mathrm{C}$, for different ambient relative humidities, in order to check hypothesis of Reay\& Allen, McKenzie $\mathcal{E}$ Bahu. (b) Comparison of predicted drying times at $40^{\circ} \mathrm{C}$, as obtained by extrapolation from $30^{\circ} \mathrm{C}$ with the method of McKenzie and Bahu (dotted lines), with the numerical solution of the diffusion equation (drawn lines), for two ambient relative humidities. 
content $X^{*}$. It is clear that in the present case the effect of relative humidity cannot be accounted for in this way, and that application would again lead to large deviations in drying times. In Fig. $6 \mathrm{~b}$ the prediction of the temperature effect is tested; from the diffusion model data at $30^{\circ} \mathrm{C}$ Equation (15) has been applied to estimate the drying times at $40^{\circ} \mathrm{C}$, and the data are compared with the numerical solution for that temperature. It can be observed that drying times by the method of Equation (15) would be strongly overestimated in this way; the reason for this is that implicitly the activation energy for the drying rate is set equal to the heat of evaporation of water. For diffusion-limited products the activation energy of the diffusion coefficient is much higher.

\section{POWER-LAW METHOD OF COUMANS}

In developments started by Schoeber's Regular Regime Theory, Liou and subsequently Coumans developed elegant short-cut calculation methods for the case of power-law dependent diffusion coefficients $(9,10)$. Lievense analyzed his drying data by means of these methods and showed that for the $L$. Plantarum preparation this type of diffusion coefficient applies well; this is also illustrated by Fig.1. In this theory the three main regions are distinguished : the constant-activity (CA) period, the Penetration Period (PP), and the Regular Regime (RR). The CA-period for non-shrinking systems in constant surroundings corresponds to the constant-rate period; the PP occurs at highintensity drying, when after the CA-period the profiles stil have to penetrate to the core of the particle, and the RR sets in when the core concentration starts to decrease.

For the dependence as used here :

$\mathrm{D}=\mathrm{D}_{0} \mathrm{X}^{\mathrm{a}}$

we may simplify the dimensionless relations of Coumans as :

$\mathrm{F} \equiv \mathrm{j}_{\mathrm{w}, \mathrm{i}} \mathrm{R}$

$\bar{F}_{\mathrm{ca}}=\mathrm{j}_{\mathrm{w}, \mathrm{cr}} \mathrm{R}$

$F_{p p}=D_{0}\left(X_{0}-X_{e}\right) \rho_{s} \frac{4}{\pi}\left[\frac{1.42}{a+1.42}\right]^{1.98}\left(\frac{X_{0}-X_{e}}{X_{0}-X}-0.71(1.25)^{a}\right)$

$\mathrm{F}_{\mathrm{rr}}=\mathrm{D}_{0}\left(\mathrm{X}_{0}-\mathrm{X}_{\mathrm{e}}\right) \rho_{\mathrm{s}} \frac{1}{2} \frac{S h_{\mathrm{d}}}{\mathrm{a}+1}\left(\frac{X-X_{\mathrm{e}}}{X_{0}-X_{\mathrm{e}}}\right)^{\mathrm{a}+1}$

$\operatorname{Sh}_{\mathrm{d}}=10.87-5.09\left(\frac{\mathrm{a}}{\mathrm{a}+2}\right)$ 


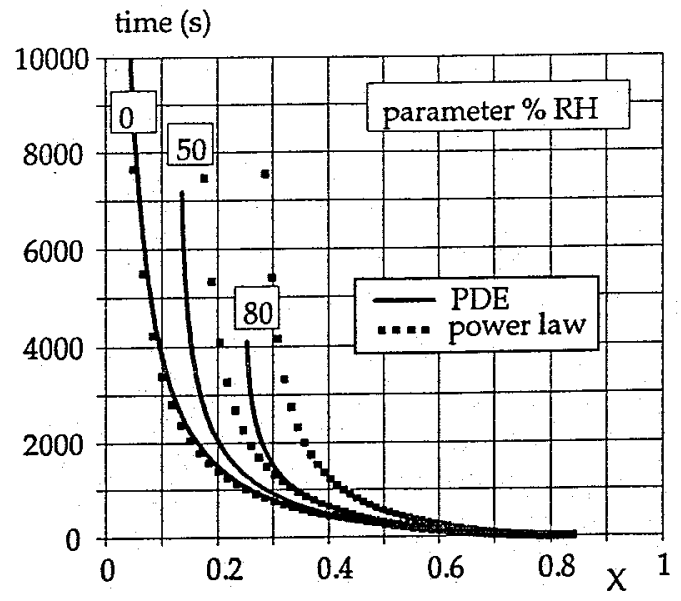

FIGURE 7. Drying times calculated according to the power-law regular regime method of Coumans (symbols) compared with numerical solution of the diffusion equation (drawn lines), for isothermal drying at particle temperature $30^{\circ} \mathrm{C}$.

in which $\mathrm{F}$ is a so-called flux-parameter, and the transition between the various regimes may be summarized as determined by the application of the lowest of the three. For the CA-period of course $\mathrm{F}$ is equal to the value following from the external flux at $100 \%$ interfacial water activity. As indicated by the various authors a variable interfacial concentration should be handled by determining by trial and error the momentary value of $X_{i}$, and substitution of this for $X_{e}$ in Equation (17). In Fig. 7 the results are shown in comparison with the full diffusion model. At $\mathrm{RH}=0$ we have a very good correspondence as may be expected because of the way the short-cut methods have been developed, and the diffusion coefficient used has been determined along these ways. For higher relative humidities however we see considerable deviations; the short-cut method predicts much larger drying times than the full diffusion model.

\section{CONCLUSION}

For the case of concentration-dependent diffusion as encountered in foods and bioproducts, examination of a sample case with various lumped-parameter 
methods shows that these are not suitable at present for reasonably accurate predicton of drying rates and thus of drying times. The main factor in this is the effect of the air relative humidity, and thus of the driving force and interfacial concentration; both in experimental work and in model studies this has had only very scarce attention as yet. Since it is highly relevant for fluidized bed drying it is of great interest and importance to set up systematic studies for development of more accurate lumped-parameter and short-cut methods.

\section{REFERENCES}

1. Lievense, L.C., Verbeek, M.A.M., Meerdink, G. \& van 't Riet, K., 1990, Inactivation of Lactobacillus Plantarum during drying. I. Measurement and modelling of the drying process, Bioseparation, 1, pp 149-159

2. Krischer, O. \& Kast, W., 1978, Die wissenschaftlichen Grundlagen der Trocknungstechnik, $1^{\text {ster }}$ Band, Springer Verlag, Berlin

3. Keey, R.B., 1978, Introduction to industrial drying operations, Pergamon Press, Oxford

4. Reay, D. \& Allen, R.W.K., 1982, The effect of bed temperature on fluid bed batch drying curves, J. Separ. Proc. Technol., 3 (4), pp. 11-13

5. McKenzie, K.A. \& Bahu, R.E., 1991, Material model for fluidised bed drying, Drying 91, A.S. Mujumdar \& I. Filkova, Eds, pp. 130-141

6. Strumillo, C. \& Kudra, T., Drying : Principles, applications and design, Gordon \& Breach Science Publishers, New York, pp. 154

7. Schoeber, W.J.A.H., 1976, Regular regimes in sorption processes, Ph.D. Thesis, Eindhoven University of Technology

8. Schoeber, W.J.A.H., 1978, A short-cut method for the calculation of drying rates in case of a concentration-dependent diffusion coefficient, Proc. $1^{\text {st }}$ Int. Drying Symp., Montreal, Hemisphere Publ. Corp., pp 1 - 9 
9. Liou, J.K. \& Bruin, S., 1982, An approximate method for the non-linear diffusion problem with a power relation between diffusion coefficient and concentration. I. Computation of desorption times, Int.J. Heat Mass Transfer, 25, pp. 1209-1220

10 Coumans, W.J., 1987, Power law diffusion in drying processes, Ph.D. Thesis, Eindhoven University of Technology

11. Kerkhof, P.J.A.M., 1994a, Modelling fluidized bed drying of products with internal diffusion, manuscript in preparation

12. Kerkhof, P.J.A.M., 1994b, The role of theoretical and mathematical modelling in scale-up, Drying Technology, 12 (1\&2), 1-46

13. Kerkhof, P.J.A.M., 1994c, Relations between local and effective air-side mass and heat transfer coefficients in fluidized bed drying, Drying Technology, 12 (5), 1191-1210

14 Kerkhof, P.J.A.M., \& Schoeber, W.J.A.H., 1974, Theoretical modelling of the drying behaviour of droplets in spray dryers, Advances in Preconcentration and Dehydration, Ed. A. Spicer, pp. 349-406

15. Strumillo, T., Grabowski, S., Kaminski, W. \& Zbicinski, I., 1989, Simulation of fluidized bed drying of biosynthesis products, Chem. Eng. Process, 26 (2), pp. $139-145$ 